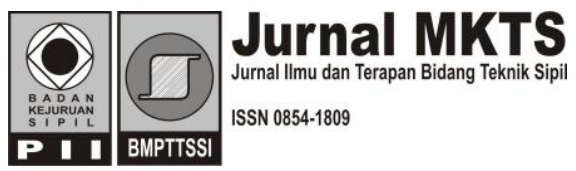

\title{
Model Penilaian untuk Kematangan Perencanaan Keselamatan dalam Tahap Pra Konstruksi
}

\author{
Bambang Endroyo \\ Jurusan Teknik Sipil Universitas Negeri Semarang, \\ Kampus Sekaran Gunungpati Semarang \\ E-mail: bbendroyo@yahoo.com \\ Akhmad Suraji \\ Jurusan Teknik Sipil Universitas Andalas, Padang \\ Kampus Limau Manis, Pauh, Sumatra Barat, Padang, 25163 \\ E-mail: -
}

\begin{abstract}
The construction sector still has a low achievement in safety issues. Fatal accident rate in construction is higher than average rate in other industries. Because of it, need some attention to minimize the rate of accident in construction. This research examined the key factors of safety planning in the pre-construction stage, and it was based on the theories of accidents causation having the upstream approach. Some theories were: Constraint-Response Theory (CR); Construction Design Management (CDM), and the Process Protocol (Pp). This research broke down the three theories above (CR; CDM; Pp) into the concept of the key factors of safety planning in pre-construction. Then, the concept was verified by construction practitioners and academician, using Delphi method three rotations. During the verification, from the first to the third round, there were reduction and the addition concept and language appropriateness. The findings of this research were assessment models of maturity safety planning in the pre construction stages. There were two models, the model of "radar chart" or MISAP 1 and the model of "worksheet" or MISAP 2.
\end{abstract}

Keywords: Preconstruction, Accident, Safety, Key factor, Upstream approach.

\begin{abstract}
Abstrak
Sektor konstruksi masih mempunyai prestasi yang rendah dalam persoalan keselamatan. Angka kecelakaan fatal di proyek konstruksi lebih tinggi dibanding angka rata-rata pada industri lainnya. Oleh sebab itu perlu perhatian untuk menekan tingkat kecelakaan konstruksi menjadi seminimum mungkin. Riset ini meneliti factor-faktor kunci perencanaan keselamatan pra konstruksi. Studi ini diselenggarakan dengan mendasarkan pada teori penyebab kecelakaan yang mempunyai pendekatan hulu (upstream approach). Beberapa teori itu adalah: Constraint-Response Teori (C-R); Construction Design Management (CDM); dan Process Protocol (Pp). Riset ini mem-break down ke tiga teori di atas (C-R; CDM; Pp) ke dalam konsep factor-faktor kunci perencanaan keselamatan pra konstruksi. Kemudian, konsep diverifikasi oleh praktisi konstruksi dan akademisi, dengan menggunakan tiga perputaran metode delphi. Selama verifikasi, dari putaran pertama sampai ketiga, terjadi pengurangan dan penambahan konsep dan juga penyelarasan bahasa. Hasil riset adalah model penilaian untuk kematangan perencanaan keselamatan pada tahap pra konstrusi. Ada dua model, suatu model "diagram radar" yang diberi nama MISAP 1 dan model "lembar kerja" yang diberi nama MISAP 2.
\end{abstract}

Kata-kata kunci: Pra konstruksi, Kecelakaan, Keselamatan, Faktor kunci, Pendekatan hulu. 


\section{Pendahuluan}

Di banyak negara, angka kecelakaan fatal di industri konstruksi adalah yang lebih tinggi dibanding industri lain (Alves Diaz, 1995; Suraji, 1997a; Duff, 1998). Di tahun 2005, tingkat kecelakaan fatal di AS adalah 4 tiap 100.000 pekerja dan di industri konstruksi adalah 11,1 tiap 100.000 pekerja (Departemen Tenaga Kerja AS, 2007). Di Inggris, rata-rata tingkat kecelakaan fatal adalah 0,5 tiap 100.000 pekerja sementara di industri konstruksi adalah 2 tiap 100.000 pekerja (www.hse.gov.uk, 11/09/2010). Di negara-negara berkembang, angka tersebut lebih buruk lagi (Koehn, 1995). King dan Hudson menyatakan bahwa tingkat kecelakaan fatal pada negara sedang berkembang sekitar tiga kali dari angka pada negara maju. Pada masa sekarang dan yang akan datang, proyek konstruksi menjadi semakin komplek (Suhendro, 2003). Hal itu disebabkan karena meningkatnya kebutuhan individu dan sosial. Sangat mungkin suatu proyek konstruksi harus dibangun dengan desain yang sulit di tempat yang sulit pula. Johnson (1998) menyatakan bahwa desain yang sulit dapat meningkatkan resiko kecelakaan.

Untuk menekan angka kecelakaan menjadi minimal, keselamatan konstruksi perlu ditingkatkan. Rekomendasi dari Barrie (1990), Hinze (1997), dan Oberlender (2000) adalah melakukan perencanaan keselamatan konstruksi se awal mungkin dan kemudian dilaksanakan pada tahap konstruksi (Koehn, 1995). Dalam pelaksanaannya, keselamatan konstruksi harus diawasi apakah semua yang telah direncanakan itu betul-betul dilaksanakan. Berdasarkan pendapat Oberlender (2000), walaupun praktek yang sekarang menempatkan tanggung jawab keselamatan konstruksi itu kepada kontraktor, seharusnya terbentuk suatu kerjasama kelompok yang memahami dan menerapkan suatu filosofi keselamatan. Mohamed (2003) juga mengatakan bahwa pandangan tradisional yang menganggap bahwa keselamatan itu tanggung jawab kontraktor adalah tidak valid. Suraji (2000) menyatakan bahwa keselamatan merupakan tanggung jawab semua yang terlibat di dalam proses konstruksi.

Perencanaan harus matang sebelum dilaksanakan. Kasus-kasus kecelakaan konstruksi yang telah terjadi mengindikasikan adanya perencanaan yang tidak matang. Untuk menilai apakah suatu perencanaan keselamatan pra konstruksi itu sudah matang, diperlukan alat penilaian. Riset ini berusaha membuat model penilaian dengan merangkum dari beberapa teori pencegahan kecelakaan, kemudian diverifikasi oleh akademisi dan praktisi dan akhirnya divalidasi oleh para praktisi konstruksi dan proyek-proyek konstruksi.

\section{Keselamatan, kecelakaan dan teori penyebab kecelakaan konstruksi}

Definisi keselamatan konstruksi sudah banyak diusulkan oleh para ahli antara lain Davies (1996), Levitt (1993), Mitropoulos (2005), dan beberapa institut antara lain OHSAS dan NSC (The National Safety Council). Dari beberapa pendapat dari semua ahli di atas, keselamatan konstruksi adalah suatu usaha untuk mengenali dan mengendalikan bahaya, insiden, kecelakaan, dan penyakit akibat kerja yang diperkirakan akan terjadi kepada karyawan, para pekerja temporer, personil pemborong, pengunjung dan orang lain di (dalam) tempat kerja dan sekitarnya, agar bebas dari resiko yang tak dapat diterima. Suraji dan Bambang Endroyo (2009) menyatakan keselamatan konstruksi itu adalah keselamatan untuk orangorang yang bekerja di (dalam) proyek konstruksi, keselamatan untuk yang masyarakat/publik dari efek pelaksanaan proyek konstruksi, keselamatan properti yang dipakai untuk pelaksanaan proyek dan keselamatan lingkungan di mana proyek konstruksi dilaksanakan. Definisi kecelakaan konstruksi juga diusulkan oleh para ahli dan lembaga: Hinze (1977), Rowlinson (1997), NSC, OHSAS 18001:1999 bahwa kecelakaan konstruksi adalah peristiwa tidak direncanakan, yang tidak diinginkan, tak diduga, tak terkendalikan, menghasilkan kerusakan pada peralatan, menyebabkan penyakit dan bahkan kematian pada pekerja, atau para orang yang terlibat.

Beberapa tenaga ahli telah mengusulkan teori penyebab kecelakaan konstruksi. Teori itu dapat dikelompokkan ke dalam teori individual dan teori organizational/management. Teori penyebab kecelakaan yang menggunakan paradigma individu dikemukakan oleh para ahli pada permulaan abad 19. The Pure Chance Theory menyatakan suatu kecelakaan tergantung seluruhnya pada atas kesempatan. Itu sebagai suatu peristiwa di luar kemampuan manusia. Accident-Proneness Theory memusatkan atas faktor pribadi yang berhubungan dengan penyebab kecelakaan (Hinze, 1997). Goals-Freedom-Alertness Theory, menyataan kecelakaan itu sebagai perilaku kerja yang bermutu rendah yang terjadi di dalam suatu iklim psikologis tak ada penghargaannya (Hinze, 1997). Adjustment-Stress Theory menyatakan bahwa faktor-faktor di luar individu pekerja dapat menjadi penyebab kecelakaan (Hinze, 1997).

Pada teori-teori berikut, paradigma organisasi/ manajemen telah dipertimbangkan sebagai faktor penting penyebab kecelakaan. The Domino Theory 
dari Heinrich yang diusulkan pada tahun 1930an menyatakan bahwa perilaku manusia yang kurang efisien didahului dan dipengaruhi oleh faktor sosial dan lingkungan yang dapat mengakibatkan keadaan yang tidak selamat, kecelakaan dan lukaluka (Suraji, 2001). Perilaku tentang faktor-faktor yang terlibat dalam kecelakaan adalah serupa dengan robohnya kartu domino ketika diganggu. Jika yang satu roboh, yang lainnya akan roboh juga. The Fishbone Model diusulkan oleh Nishishima tahun 1989, membagi penyebab kecelakaan dalam empat klasifikasi, yaitu manusia, peralatan, pekerjaan dan manajemen (Suraji, 2001). The Tripod Model (TM) diusulkan oleh Reason pada tahun 1990 tentang penyebab kecelakaan, menghadirkan interkoneksi antara kecelakaan, tindakan tak aman dan resident pathogen.

Resident pathogen adalah sumber kegagalan yang laten yang meliputi disain dan konstruksi yang kurang efisien, kegagalan manajemen, kesalahan pemeliharaan, kelemahan komponen, prosedur tidak baik dan pelanggaran rutin (Suraji, 2001). The Distraction Theory (DT) diusulkan oleh Hinze tahun 1996 (Suraji, 2001). Teori ini menganggap bahwa kecelakaan dimungkinkan karena pengacauan pekerja yang disebabkan oleh sumbersumber fisik ataupun mental. Ada kemungkinan produktivitas dan keselamatan berlangsung secara bertentangan dengan satu sama lain, artinya bila produktivitasnya tinggi, kemungkinan keselamatannya rendah. Ada pula kemungkinan bahwa keselamatan dan produktivitas dapat dicapai secara serempak, yang berarti produktivitasnya tinggi dan keselamatannya tinggi (Hinze, 1997).

Teori-teori dengan paradigma individu dan paradigma organisasi-manajemen yang telah diuraikan di atas telah lama menjadi dasar bagi pencegahan kecelakaan konstruksi. Teori-teori tersebut lebih banyak meninjau kecelakaan dari arah tempat kerja yaitu dari arah hilir (downstream). Sementara itu teori tentang penyebab kecelakaan konstruksi masih selalu dikembangkan oleh para ahli, untuk dapat lebih menjelaskan fenomena yang menjadi penyebab suatu kecelakaan. Saat ini, para peneliti tidak hanya menggunakan pendekatan hilir, tetapi juga menggunakan pendekatan hulu dalam mempelajari penyebab kecelakaan. Sesuai dengan judul artikel ini, akan dipelajari secara rinci beberapa teori yang relevan pada yaitu Constraint-Respone Theory, Prosess Protocol, dan Construction Design Management.

Constraint-Response Theory diusulkan oleh Suraji (2001), memandang bahwa kecelakaan konstruksi di tempat kerja, sebetulnya bersumber dari banyak faktor, tidak saja faktor pekerja dan pengorganisasian di tempat kerja (job-site) saja, tetapi tahap perencanaan oleh perencana dan tahap konsep oleh client juga berpengaruh. Orang-orang yang terlibat dalam proyek konstruksi dapat menciptakan faktor-faktor potensi yang mendorong ke arah kecelakaan. Faktor-faktor penyebab dapat yang berhubungan dengan teknis, yang berhubungan dengan operasional, yang berhubungan dengan lingkungan, dan faktor yang terkait dengan manajerial (Suraji, 2001). Model ini memetakan faktor penyebab kecelakaan dalam: distal factor dan proximal factor yang mungkin dihasilkan oleh klien, regu klien, para perancang, para pemborong, dan pemborong bawahan (sub kontraktor).

Construction Design Management adalah peraturan tentang manajemen keselamatan dan kesehatan konstruksi dasar penelitian-penelitian yang berwawasan pendekatan upstream. CDM diperkenalkan pada tahun 1994 dan kemudian direvisi pada taun 2007. CDM berbeda dari peraturan yang lebih awal sebab mempunyai suatu sistem yang dimana tiap-tiap pekerja harus menjadi bagian dari sistem manajemen keselamatan dan kesehatan selama proyek (Fink,1997). Beberapa item dalam CDM adalah (Davies dan Tomasin, 1996; Fink, 1997; http://www.hse.gov.uk/ construction/cdm.htm):

a. client berperan mengendalikan keselamatan yang diajukan oleh penawaran kontraktor;

b. planning supervisor melakukan koordinasi tentang keselamatan dan kesehatan konstruksi di dalam perencanaan dan perancangan proyek konstruksi;

c. designer harus bertanggung jawab atas keselamatan dari disain mereka;

d. kontraktor utama merencanakan, mengatur dan mengkoordinasi keselamatan dan kesehatan selama pekerjaan konstruksi. Kontraktor utama pada umumnya mengatur kontraktor untuk pelaksanaan pekerjaan;

e. kontraktor perlu mempertimbangkan keselamatan di dalam tahap penawaran dan semua tahap pada proyek konstruksi.

Process Protocol, dikembangkan oleh Universitas Salford sejak 1998, di dalam usaha untuk meningkatkan proses desain dan konstruksi (Wu S. et. al., 2001). Process Protocol dibagi menjadi empat langkah yaitu:

a. Tahap Pre-Project: berhubungan dengan pertimbangan bisnis yang strategis tentang segala potensi proyek yang bersumber kepada kebutuhan client. Tahap ini terdiri dari langkah nol sampai tiga. 
b. Tahap Pre-Construction: yang menggambarkan kebutuhan client ke dalam suatu disain yang sesuai. Tahap ini terdiri dari langkah empat sampai langkah enam.

c. Tahap Construction: merupakan penyelesaian proyek. Tahap ini terdiri dari langkah tujuh dan delapan.

d. Tahap Post-Construction/Completion: memo nitor secara terus menerus dan mengatur pemeliharaan yang diperlukan dari pembangunan fasilitas. Tahap ini terdiri dari langkah kesembilan.

Walaupun Process Protocol ini meninjau keseluruhan proyek, namun lebih memusatkan pada tahap pra konstruksi, terlihat dari 10 langkah yang ada, 7 langkah adalah pada tahap sebelum tahap konstruksi. Oleh karena itu, teori ini adalah sangat relevan dengan topik yang diselenggarakan.

\section{Kematangan perencanaan keselamatan pada tahap pra konstruksi.}

Di dalam proyek konstruksi, perencanaan mempunyai peran penting sebab keputusan strategis dan anggaran proyek ditetapkan pada tahap ini. Beberapa gagasan dari pemilik diuraikan di dalam suatu dokumen perencanaan dan kemudian harus dilaksanakan oleh pemborong. Suatu perencanaan perlu dibuat secara matang sebelum dilaksanakan. Suatu perencanaan yang belum matang dapat menyebabkan suatu potensi yang rendah suatu perencanaan proyek konstruksi di dalam pencegahan kecelakaan.

Menurut Echols (1990), perencaan yang matang adalah perencanaan yang sudah betul-betul dipikirkan. Menurut Kerzner (1995), Reksohadiprojo (1990), dan Hasibuan (2005), perencanaan proyek harus realistis, komprehensif, integratif, sistematis dan mudah diukur. Realistis berarti sesuai dengan kenyataan yang ada. Komprehensif berarti mencakup semua pihak yang berperan dalam pelaksanaan proyek menjadi bagian dalam perencanaan. Integratif berarti menyatukan dan mengkoordinasi unsur-unsur berbeda ke dalam sesuatu yang utuh, yaitu suatu output bagian yang satu menjadi input bagian yang lain secara proporsional. Sedang sistematis diartikan sebagai kegiatan yang sesuai dengan perencanaan, berdasar pada suatu sistem atau metode, rangkaian tindakan yang rapi dan teratur. Untuk menilai kematangan suatu perencanaan keselamatan pra-konstruksi, diperlukan suatu model penilaian. Penelitian ini berusaha membuat model penilaian untuk menentukan kematangan perencanaan pada tahap pra-konstruksi.
Secara umum tujuan penelitian ini adalah mendapatkan suatu sistem penilaian kematangan perencanaan pra-konstruksi. Berdasarkan tujuan tersebut, penelitian ini akan:

a. Mengkaji peran perencanaan pra-konstruksi dalam mewujudkan keselamatan konstruksi

b. Memetakan peran masing-masing pihak (partisipan proyek) dalam perencanaan keselamatan pra-konstruksi

c. Mengidentifikasi faktor-faktor kunci kematangan perencanaan keselamatan prakonstruksi.

d. Menentukan parameter kematangan masingmasing faktor-faktor kunci perencanaan keselamatan pra-konstruksi

e. Menyusun penilaian masing-masing faktor kunci kematangan perencanaan keselamatan pra-konstruksi.

f. Menyusun sistem penilaian kematangan perencanaan keselamatan pra-konstruksi

\section{Metode Penelitian}

Berdasar pada teori penyebab kecelakaan yang terbaru, peneliti menyusun konsep instrumen yang pertama, yang dinamakan draft 0. Kemudian, dengan questionare melalui, email, konsep tersebut diverifikasi oleh akademisi dan praktisi dan hasilnya dinamakan draft 1 . Setelah itu, melalui tiga ronde FGD (diskusi kelompok), draft 1 juga diverifikasi oleh akademisi dan praktisi terpilih. Selama verifikasi, dari putaran pertama sampai ketiga, ada pengurangan dan penambahan dari konsep faktor-faktor kunci uraian serta penyempurnaan bahasa. Hasil FGD adalah draft 2 dan draft 3. Akhirnya, melalui email questionare, draft 3 divalidasi oleh praktisi konstruksi dan diperoleh draft akhir (draft 4). Selanjutnya dilakukan validasi model penilaian yang diusulkan. Model penilaian yang sudah valid tersebut di aplikasikan ke proyek-proyek konstruksi.

\section{Pengumpulan Data dan Analisis Data}

Pengumpulan data menggunakan questionare melalui email, FGD (Focus Group Discussion), dan observasi ke proyek konstruksi. Analisis data menggunakan analisis statistik deskriptif dan analisis statistik SEM PLS (Structural Equation Model-Partial Least Square). Analisis data digunakan untuk verifikasi dan validasi instrumen penilaian yang diusulkan. Butir pertanyaan yang memiliki factor loading lebih dari 0,5 dinyatakan valid.

Di samping analisis validitas juga dilakukan analisis reliabilitas. Dengan analisis PLS smart, 
bila besarnya composite reliability di atas 0,70 maka model penilaian dinyatakan reliabel.

\section{Skema penelitian}

Skema penelitian ditunjukkan di Gambar 1.

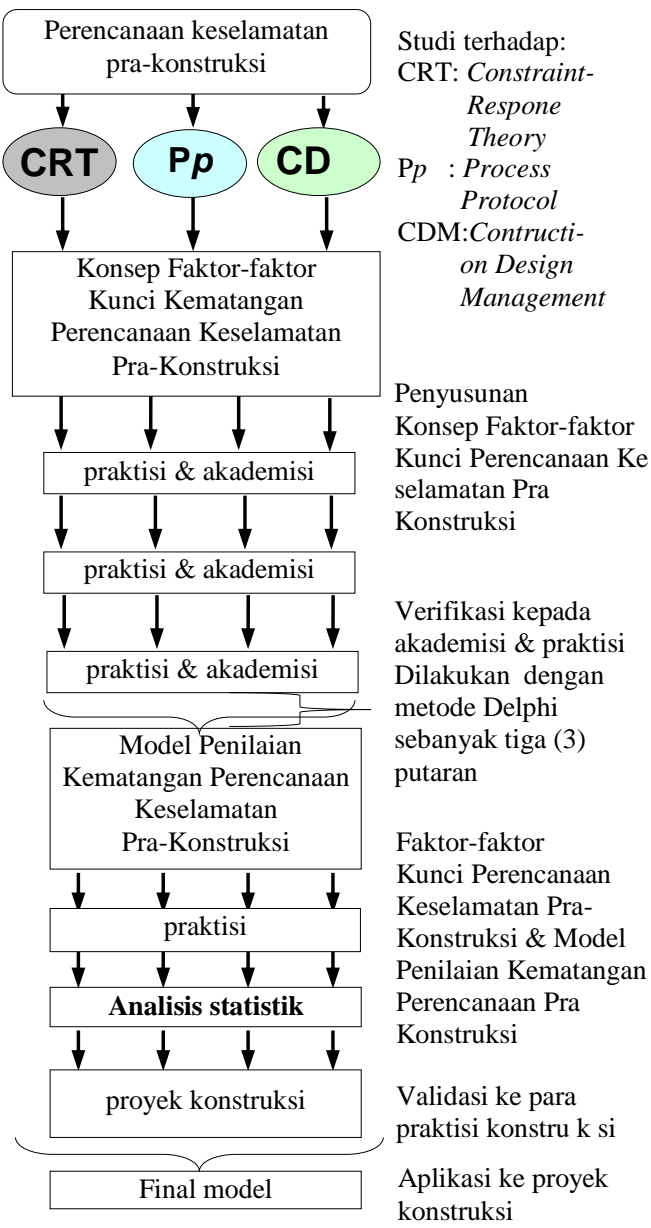

Gambar 1. Skema Penelitian

\section{Hasil Penelitian}

\section{Deskripsi responden penelitian}

Questionare dikirim kepada 36 responden, menggunakan eSurveysPro.com Tiap responden dapat mengirim satu sampai tiga data proyek yang pernah dialami, sehingga terkumpul 74 jawaban. Responden penelitian terdiri dari para akademisi $(45 \%)$, praktisi $(50 \%)$ dan lainnya $(5 \%)$. Mereka berpendidikan S3 (50\%), S2 (33\%), S1 (17\%). Pengalaman kerja para responden, kurang 3 tahun (5\%), 3 s/d 5 tahun (17\%), 5 s/d 10 tahun (5\%), dan lebih dari 10 tahun (72\%).

\section{Hasil Penelitian}

Hasil uji validitas, ada 11 butir pertanyaan yang tidak valid dan di drop-out dari model penilaian karena besarnya factor loading kurang dari 0,5. Butir pertanyaan yang valid sebanyak 27 butir. Hasil uji reliabilitas, besarnya composite reliability di atas 0,70. Dari hasil perhitungan PLSsmart didapat besarnya composite reliability adalah: peran owner $(\mathrm{O})=0,856$; peran konsultan $(\mathrm{S})=$ 0,867 ; peran kontraktor $(\mathrm{N})=0,892$ dan peran Stakeholder $(\mathrm{H})=0,891$. Dengan demikian instrumen penelitian telah memenuhi syarat validitas dan reliabilitas.

Hasil penelitian adalah model penilaian kematangan perencanaan keselamatan pada tahap pra konstruksi (Maturity Model of Safety Planning for Pre Construction Stage), disingkat MISAP. Ada dua buah model yaitu model "diagram radar" yang dinamakan MISAP 1 dan model "lembar kerja" diagram radar yang dinamakan MISAP 2.

Hasil dari konsepsi, verifikasi dan validasi ditulis pada Tabel 1. Hasil konsepsi pada kolom (a), hasil verifikasi pada kolom (b), dan faktor-faktor kunci sebagai indikator kematangan perencanaan keselamatan pada tahap pra konstruksi tertulis pada kolom (c). Sedang petunjuk indikator yang valid tertulis pada kolom $(\mathrm{d})$ 
Tabel 1. Rangkuman hasil sudi literatur

(a), Hasil verifikasi putaran pertama sampai ketiga (b dan c), dan hasil validasi model (d)

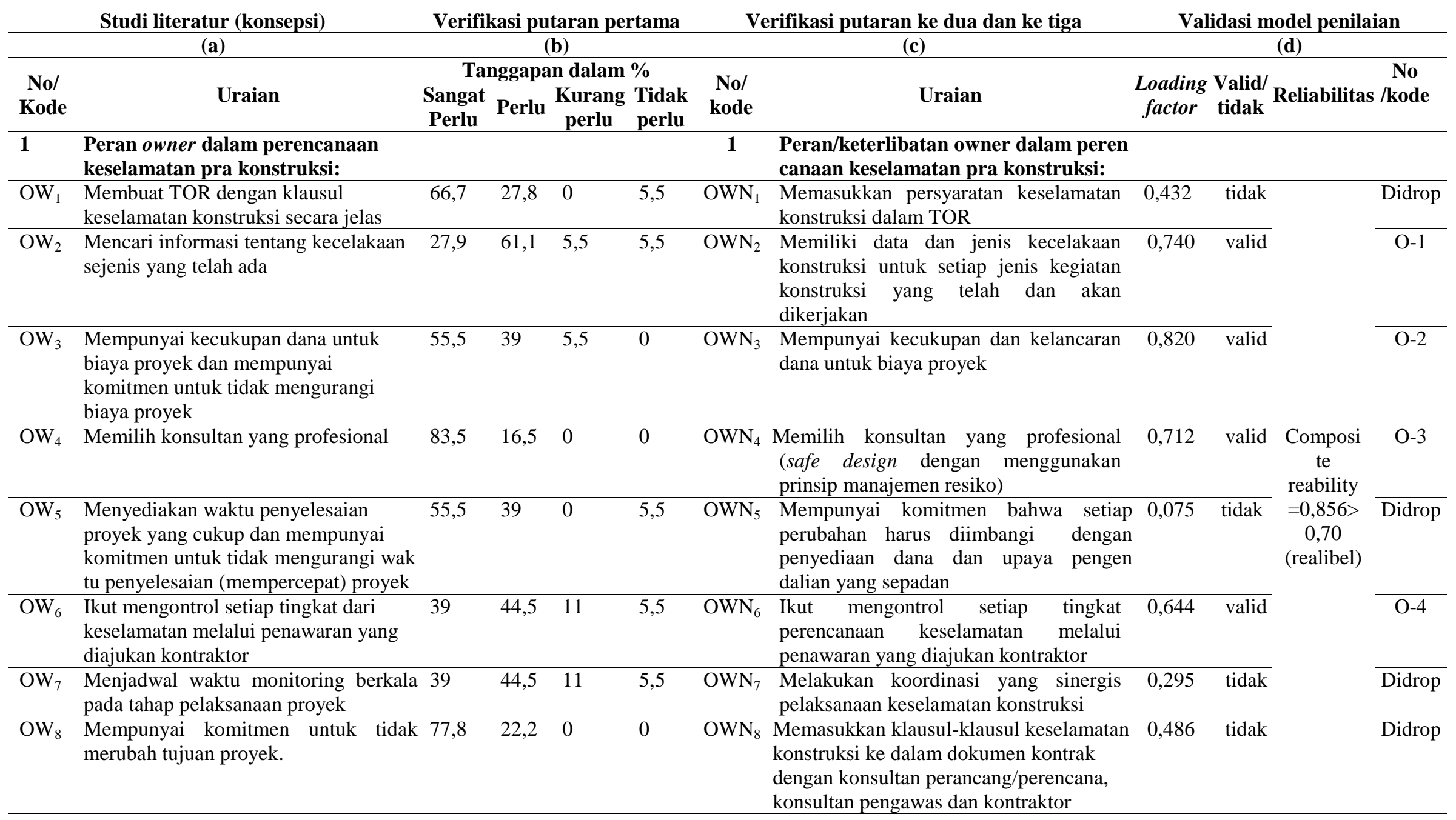




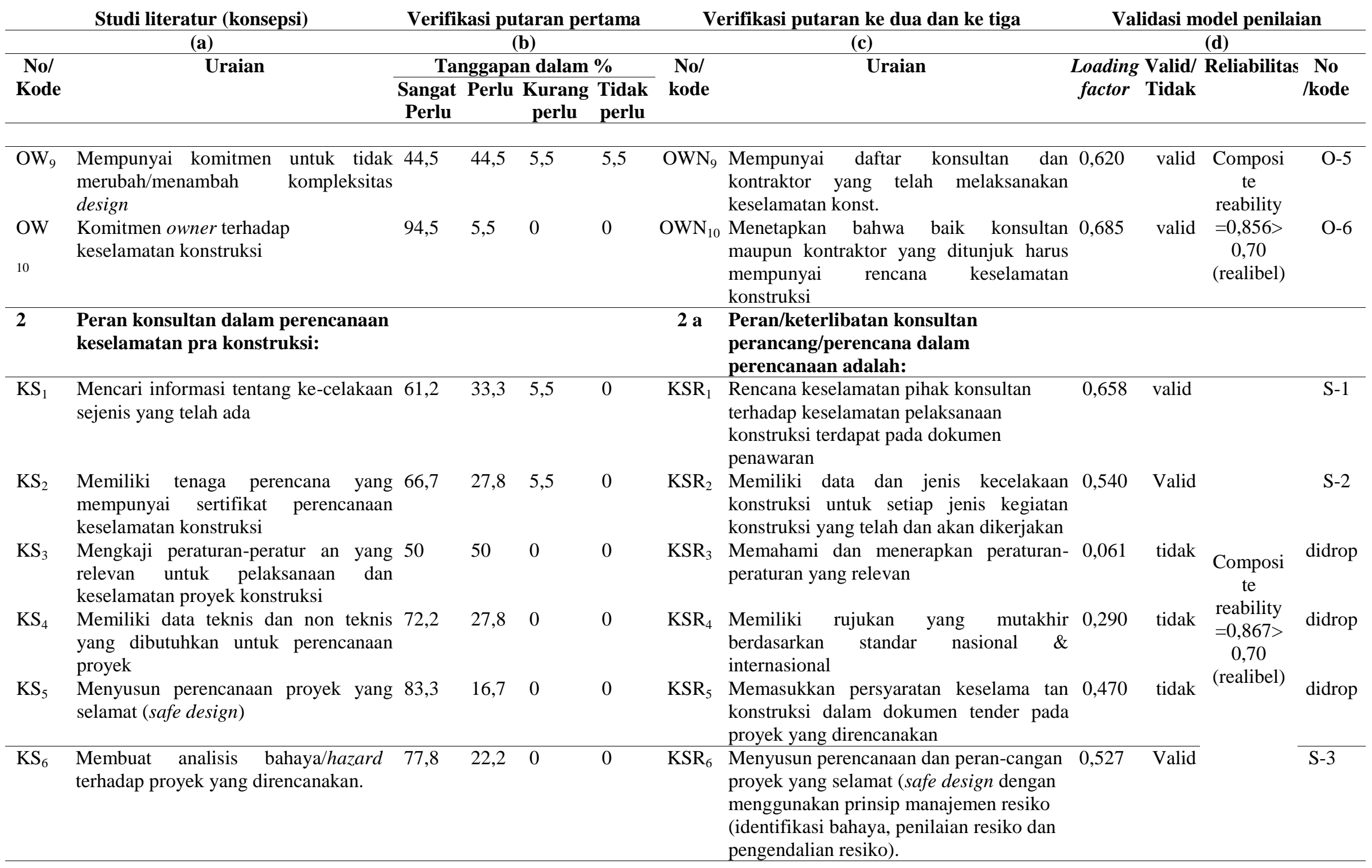




\begin{tabular}{|c|c|c|c|c|c|c|c|c|c|c|c|}
\hline \multirow{2}{*}{\multicolumn{2}{|c|}{$\frac{\text { Studi literatur (konsepsi) }}{\text { (a) }}$}} & \multirow{2}{*}{\multicolumn{4}{|c|}{$\begin{array}{c}\text { Verifikasi putaran pertama } \\
\text { (b) }\end{array}$}} & \multirow{2}{*}{\multicolumn{2}{|c|}{$\begin{array}{l}\text { Verifikasi putaran ke dua dan ke tiga } \\
\text { (c) }\end{array}$}} & \multicolumn{4}{|c|}{ Validasi model penilaian } \\
\hline & & & & & & & & & & \multicolumn{2}{|c|}{ (d) } \\
\hline \multirow{2}{*}{$\begin{array}{l}\text { No/ } \\
\text { Kode }\end{array}$} & \multirow[t]{2}{*}{ Uraian } & \multicolumn{4}{|c|}{ Tanggapan dalam \% } & \multirow{2}{*}{$\begin{array}{l}\text { No/ } \\
\text { kode }\end{array}$} & \multirow[t]{2}{*}{ Uraian } & \multirow{2}{*}{$\begin{array}{l}\text { Loading } \\
\text { factor }\end{array}$} & \multirow{2}{*}{$\begin{array}{l}\text { Valid/ } \\
\text { Tidak }\end{array}$} & Reliabilitas & No \\
\hline & & $\begin{array}{l}\text { Sangat } \\
\text { Perlu }\end{array}$ & Perlu & $\begin{array}{c}\text { Kurang } \\
\text { perlu }\end{array}$ & $\begin{array}{l}\text { Tidak } \\
\text { perlu }\end{array}$ & & & & & & /kode \\
\hline $\mathrm{KS}_{7}$ & $\begin{array}{l}\text { Menyusun pre tender safety planning } \\
\text { (draft 1) tentang keselamatan proyek } \\
\text { rencana. }\end{array}$ & 61,2 & 33,3 & 5,5 & 0 & $\mathrm{KSR}_{7}$ & $\begin{array}{l}\text { Memiliki tenaga perencana yang } \\
\text { mempunyai sertifikat pelatihan } \\
\text { keselamatan perancangan dan } \\
\text { perencanaaan (semacam construction } \\
\text { design management). }\end{array}$ & 0,871 & valid & & S-4 \\
\hline $\mathrm{KS}_{8}$ & $\begin{array}{l}\text { Menyiapkan instrumen penilaian } \\
\text { tentang pelaksanaan keselamatan } \\
\text { konstruksi. }\end{array}$ & 66,7 & 27,8 & 5,5 & 0 & $\mathrm{KSR}_{8}$ & $\begin{array}{l}\text { Menyiapkan format penilaian pemenang } \\
\text { tender termasuk kriteria keselamatan } \\
\text { konstruksi. }\end{array}$ & 0,799 & valid & $\begin{array}{l}\text { te } \\
\text { reability } \\
=0,867>\end{array}$ & S-5 \\
\hline $\mathrm{KS}_{9}$ & $\begin{array}{l}\text { Memiliki pengalaman perencanaan } \\
\text { proyek sejenis. }\end{array}$ & 61,2 & 38,8 & 0 & 0 & & & & & $\begin{array}{c}0,70 \\
\text { (realibel) }\end{array}$ & \\
\hline $\mathrm{KS}_{10}$ & $\begin{array}{l}\text { Memperbaiki } \begin{array}{l}\text { pre-tender } \\
\text { planning/draft } \\
\text { rencana. }\end{array} \\
\text { rencty }\end{array}$ & 66,7 & 27,8 & 5,5 & 0 & & & & & & \\
\hline 3 & 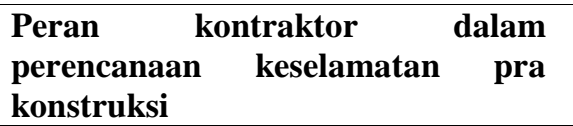 & & & & & $2 \mathbf{b}$ & $\begin{array}{l}\text { Peran/keterlibatan konsultan Pengawas } \\
\text { dalam Perencanaan Keselamatan Pra } \\
\text { Konstruksi: }\end{array}$ & & & & \\
\hline $\mathrm{KN}_{1}$ & $\begin{array}{l}\text { Mempelajari pre tender safety plan } \\
\text { (rencana keselamatan pra-konstruksi) }\end{array}$ & 100 & 0 & 0 & 0 & $\mathrm{KSW}_{1}$ & $\begin{array}{l}\text { Mengajukan proposal rencana } \\
\text { pengawasan proyek termasuk pelaksanaan } \\
\text { rencana keselamatan proyek }\end{array}$ & 0,686 & Valid & & S-6 \\
\hline $\mathrm{KN}_{2}$ & $\begin{array}{l}\text { Mencari informasi tentang kecelakaan } \\
\text { sejenis yang telah ada }\end{array}$ & 77,8 & 16,7 & 5,5 & 0 & $\mathrm{KSW}_{2}$ & $\begin{array}{l}\text { Menyiapkan format pelaporan hasil pengawasal } \\
\text { pelaksanaan keselamatan proyek. }\end{array}$ & 0,641 & Valid & & S-7 \\
\hline $\mathrm{KN}_{3}$ & $\begin{array}{l}\text { Mengembangkan pre tender safety } \\
\text { plan menjadi tender safety plan yang } \\
\text { disampaikan pada saat pelelangan. }\end{array}$ & 83,3 & 11,1 & 5,5 & 0 & $\mathrm{KSW}_{3}$ & $\begin{array}{l}\text { Menetapkan tenaga ahli keselamatan } \\
\text { konstruksi yang akan bertindak sebagai } \\
\text { pengawas pelaksanaan keselamatan } \\
\text { konstruksi. }\end{array}$ & 0,602 & Valid & $\begin{array}{l}\text { Composi } \\
\text { te } \\
\text { reability } \\
=0,892>\end{array}$ & S-8 \\
\hline $\mathrm{KN}_{4}$ & $\begin{array}{l}\text { Menyampaikan penawaran pe kerjaan } \\
\text { termasuk mengajukan rencana } \\
\text { keselamatan kon struksi (tender safety } \\
\text { plan). }\end{array}$ & 83,3 & 16,7 & 0 & 0 & $\mathrm{KSW}_{4}$ & $\begin{array}{l}\text { Memiliki data dan jenis kecelakaan } \\
\text { konstruksi untuk setiap jenis kegiatan } \\
\text { konstruksi yang telah dan akan } \\
\text { dikerjakan. }\end{array}$ & 0,388 & tidak & $\begin{array}{c}0,70 \\
\text { (realibel) }\end{array}$ & didrop \\
\hline $\mathrm{KN}_{5}$ & $\begin{array}{l}\text { Mempunyai pengalaman pada proyek } \\
\text { sejenis. }\end{array}$ & 77,8 & 22,2 & 0 & 0 & $\mathrm{KSW}_{5}$ & $\begin{array}{l}\text { Memahami penerapan peraturan } \\
\text { perundangan mengenai keselamatan } \\
\text { konstruksi yang relevan }\end{array}$ & 0,338 & tidak & & didrop \\
\hline
\end{tabular}




\begin{tabular}{|c|c|c|c|c|c|c|c|c|c|c|c|}
\hline & \multirow{2}{*}{$\begin{array}{c}\text { Studi literatur (konsepsi) } \\
\text { (a) }\end{array}$} & \multicolumn{4}{|c|}{$\begin{array}{l}\text { Verifikasi putaran pertama } \\
\text { (h) }\end{array}$} & \multicolumn{2}{|r|}{ Verifikasi putaran ke dua dan ke tiga } & \multicolumn{4}{|c|}{ Validasi model penilaian } \\
\hline & & & & (b) & & & $(\mathbf{c})$ & & & (d) & \\
\hline \multirow{2}{*}{$\begin{array}{l}\text { No/ } \\
\text { Kode }\end{array}$} & \multirow[t]{2}{*}{ Uraian } & \multicolumn{4}{|c|}{ Tanggapan dalam \% } & \multirow{2}{*}{$\begin{array}{l}\text { No/ } \\
\text { kode }\end{array}$} & \multirow[t]{2}{*}{ Uraian } & \multirow{2}{*}{$\begin{array}{l}\text { Loading } \\
\text { factor }\end{array}$} & \multirow{2}{*}{$\begin{array}{l}\text { Valid/ } \\
\text { Tidak }\end{array}$} & \multirow{2}{*}{ Reliabilitas } & \multirow{2}{*}{$\begin{array}{l}\text { No } \\
\text { /kode }\end{array}$} \\
\hline & & $\begin{array}{l}\text { Sangat } \\
\text { Perlu }\end{array}$ & Perlu & $\begin{array}{c}\text { Kurang } \\
\text { perlu }\end{array}$ & $\begin{array}{l}\text { Tidak } \\
\text { perlu }\end{array}$ & & & & & & \\
\hline $\mathrm{KN}_{6}$ & $\begin{array}{l}\text { Memiliki sertifikasi kesela-matan } \\
\text { konsruksi (SMK3, OHSAS). }\end{array}$ & 72,2 & 27,8 & 0 & 0 & $\mathrm{KSW}_{6}$ & $\begin{array}{l}\text { Memiliki rujukan yang mutakhir } \\
\text { berdasarkan standar nasional dan } \\
\text { internasional }\end{array}$ & 0,282 & Tidak & $\begin{array}{l}\text { Composi } \\
\text { te } \\
\text { reability }\end{array}$ & didrop \\
\hline $\mathrm{KN}_{7}$ & $\begin{array}{l}\text { Memiliki tenaga pelaksana yang } \\
\text { bersertifikat kesela-matan konstruksi } \\
\text { (misal: A2K4). }\end{array}$ & 66,7 & 33,3 & 0 & 0 & $\mathrm{KSW}_{7}$ & $\begin{array}{l}\text { Menyiapkan format penilaian kinerja } \\
\text { pelaksanaan keselamatan proyek }\end{array}$ & 0,524 & Tidak & $\begin{array}{l}=0,892> \\
\quad 0,70 \\
\text { (realibel) }\end{array}$ & didrop \\
\hline 4 & $\begin{array}{l}\text { Peran lingkungan dalam peren } \\
\text { canaan keselamatan Pra konstruksi }\end{array}$ & & & & & $3 \mathbf{a}$ & $\begin{array}{l}\text { Peran Kontraktor Utama dan Sub- } \\
\text { Kontraktor dalam Perenca-naan } \\
\text { Keselamatan Pra-Konstruksi adalah: }\end{array}$ & & & & \\
\hline $\mathrm{LK}_{1}$ & $\begin{array}{l}\text { Adanya undang-undang dan pera- } \\
\text { turan-peraturan tentang perencanaan } \\
\text { keselamatan konstruksi }\end{array}$ & 77,8 & 22,2 & 0 & & $\mathrm{KNU}_{1}$ & $\begin{array}{l}\text { Mempunyai rujukan peraturan per- } \\
\text { undangan keselamatan konstruksi yang } \\
\text { berlaku. }\end{array}$ & 0,701 & valid & & N-1 \\
\hline $\mathrm{LK}_{2}$ & $\begin{array}{l}\text { Adanya rangkuman analisis terhadap } \\
\text { kecelakaan pada proyek-proyek } \\
\text { konstruksi yang lalu }\end{array}$ & 66,7 & 27,8 & 5,5 & & $\mathrm{KNU}_{2}$ & $\begin{array}{l}\text { Mengajukan rencana keselamatan } \\
\text { konstruksi Prakontrak yang sesuai dengan } \\
\text { metode pelaksanaan yang akan digunakan }\end{array}$ & 0,713 & valid & & $\mathrm{N}-2$ \\
\hline $\mathrm{LK}_{3}$ & $\begin{array}{l}\text { Adanya studi AMDAL dari proyek } \\
\text { yang akan dilaksanakan tersebut }\end{array}$ & 55,5 & 38,8 & 5,5 & & $\mathrm{KNU}_{3}$ & $\begin{array}{l}\text { di dalam proposal penawaran. } \\
\text { Mempunyai pengalaman pada proyek- } \\
\text { proyek sejenis }\end{array}$ & 0,621 & valid & $\begin{array}{l}\text { Composi } \\
\text { te } \\
\text { reability }\end{array}$ & $\mathrm{N}=5$ \\
\hline $\mathrm{LK}_{4}$ & $\begin{array}{l}\text { Lingkungan mempunyai dam-pak } \\
\text { negatif minimal terhadap proyek } \\
\text { (banjir, gempa, angin, hujan dll) }\end{array}$ & 55,5 & 38,8 & 5,5 & & $\mathrm{KNU}_{4}$ & $\begin{array}{l}\text { Memiliki bukti telah menerapkan } \\
\text { keselamatan konstruksi (SMK3/OHSAS) }\end{array}$ & 0,808 & valid & $\begin{array}{l}=0,891> \\
\quad 0,70 \\
\text { (realibel) }\end{array}$ & N-6 \\
\hline \multirow[t]{3}{*}{$\mathrm{LK}_{5}$} & $\begin{array}{l}\text { Adanya pertimbangan ter-hadap } \\
\text { musim/cuaca saat proyek berlangsung } \\
\text { nanti }\end{array}$ & 72,2 & 27,8 & 0 & & $\mathrm{KNU}_{5}$ & $\begin{array}{l}\text { Memiliki tenaga ahli Keselamatan } \\
\text { konstruksi }\end{array}$ & 0,810 & valid & & N-3 \\
\hline & & & & & & $\mathrm{KNU}_{6}$ & $\begin{array}{l}\text { Memiliki sistem pengendalian } \\
\text { keselamatan konstruksi terhadap sub- } \\
\text { kontraktor }\end{array}$ & 0,823 & valid & & N-4 \\
\hline & & & & & & $3 b$ & $\begin{array}{l}\text { Peran/keterlibatan Subkontraktor } \\
\text { (bila ada) dalam Perencanaan } \\
\text { Keselamatan Pra Konststruksi: }\end{array}$ & & & & \\
\hline
\end{tabular}




\begin{tabular}{|c|c|c|c|c|c|c|c|c|c|c|}
\hline & \multirow{4}{*}{$\begin{array}{c}\text { Studi literatur (konsepsi) } \\
\text { (a) } \\
\text { Uraian }\end{array}$} & \multirow{2}{*}{\multicolumn{3}{|c|}{$\begin{array}{c}\text { Verifikasi putaran pertama } \\
\text { (b) }\end{array}$}} & \multirow{2}{*}{\multicolumn{2}{|c|}{$\begin{array}{l}\text { Verifikasi putaran ke dua dan ke tiga } \\
\text { (c) }\end{array}$}} & \multicolumn{4}{|c|}{ Validasi model penilaian } \\
\hline & & & & & & & & & \multicolumn{2}{|c|}{ (d) } \\
\hline \multirow{2}{*}{$\begin{array}{l}\text { No/ } \\
\text { Kode }\end{array}$} & & \multicolumn{3}{|c|}{ Tanggapan dalam \% } & \multirow[b]{2}{*}{ kode } & \multirow[t]{2}{*}{ Uraian } & \multirow{2}{*}{$\begin{array}{l}\text { Loading } \\
\text { factor }\end{array}$} & \multirow{2}{*}{$\begin{array}{l}\text { Valid } \\
\text { Tidak }\end{array}$} & Reliabilitas & S No \\
\hline & & $\begin{array}{l}\text { Sangat } \\
\text { Perlu }\end{array}$ & Perlu & $\begin{array}{c}\text { Kurang Tidak } \\
\text { perlu perlu }\end{array}$ & & & & & & /kode \\
\hline $\mathrm{LK}_{6}$ & $\begin{array}{l}\text { Aspek sosial-politis mempu-nyai } \\
\text { dampak negatif minimal terhadap } \\
\text { proyek }\end{array}$ & 61,1 & 33,3 & 5,5 & $\mathrm{KNS}_{1}$ & $\begin{array}{l}\text { Mempunyai rujukan peraturan } \\
\text { perundangan keselamatan konstruksi } \\
\text { yang berlaku }\end{array}$ & 0,605 & valid & & $\mathrm{N}-7$ \\
\hline $\mathrm{LK}_{7}$ & $\begin{array}{l}\text { Adanya jadwal kontrol internal dari } \\
\text { perusahaan (misalnya safety patrol, } \\
\text { safety meeting) }\end{array}$ & 72,2 & 22,2 & 5,5 & $\mathrm{KNS}_{2}$ & $\begin{array}{l}\text { Mengajukan rencana keselamatan } \\
\text { konstruksi prakontrak yang sesuai } \\
\text { dengan metode pelaksanaan yang akan } \\
\text { digunakan di dalam proposal penawaran }\end{array}$ & 0,592 & valid & & N-8 \\
\hline $\mathrm{LK}_{8}$ & $\begin{array}{l}\text { Adanya jadwal kontrol eksternal dari } \\
\text { asosiasi dan pemerintah (misalnya } \\
\text { audit keselamatan) pada waktu } \\
\text { pelaksanaan proyek nanti. }\end{array}$ & 55,5 & 39 & 5,5 & $\mathrm{KNS}_{3}$ & $\begin{array}{l}\text { Mempunyai pengalaman pada proyek - } \\
\text { proyek sejenis }\end{array}$ & 0,513 & tidak & & N-9 \\
\hline $\mathrm{LK}_{9}$ & $\begin{array}{l}\text { Kepedulian masyarakat tehadap } \\
\text { keselamatan }\end{array}$ & 66,7 & 33,3 & 0 & $\mathrm{KNS}_{4}$ & $\begin{array}{l}\text { Memiliki bukti telah menerapkan } \\
\text { keselanatan konstruksi }\end{array}$ & 0,226 & tidak & $\begin{array}{l}\text { Composi } \\
\text { te }\end{array}$ & Didrop \\
\hline $\mathrm{LK}_{10}$ & $\begin{array}{l}\text { Penegakan hukum terhadap pelanggar } \\
\text { undang-undang dan peraturan } \\
\text { keselamatan konstruksi }\end{array}$ & 100 & 0 & 0 & $\mathrm{KNS}_{5}$ & $\begin{array}{l}\text { Memiliki tenaga ahli keselamatan } \\
\text { konstruksi }\end{array}$ & 0,262 & valid & $\begin{array}{l}\text { reability } \\
=0,891> \\
0,70\end{array}$ & Didrop \\
\hline \multirow[t]{5}{*}{5} & $\begin{array}{l}\text { Besarnya peran partisipan terhadap } \\
\text { kematangan perencanaan } \\
\text { keselamatan pra-konstruksi: }\end{array}$ & & & & 4 & $\begin{array}{l}\text { Peran stakeholder proyek dalam } \\
\text { Perencanaan Keselamatan Pra- } \\
\text { Konstruksi: }\end{array}$ & & & (realıelo) & \\
\hline & $\begin{array}{l}\text { Owner, rata-rata } 26,66 \% \text { dibulatkan } \\
27 \%\end{array}$ & 94,5 & 5,5 & 0 & $\mathrm{STH}_{1}$ & $\begin{array}{l}\text { Pemerintah daerah dinas terkait } \\
\text { setempat mewajibkan terpenuhi-nya } \\
\text { perijinan proyek (IMB), penerapan dan } \\
\text { pengawasan kesela-matan konstruksi. }\end{array}$ & 0,720 & valid & & H-1 \\
\hline & $\begin{array}{l}\text { Konsultan, rata-rata } 27,5 \% \text { dibulatkan } \\
27,5 \%\end{array}$ & 94,5 & 5,5 & 0 & $\mathrm{STH}_{2}$ & $\begin{array}{l}\text { Pemerintah melaksanakan penegak-an } \\
\text { hukum terhadap pelanggar peraturan } \\
\text { perundangan keselamatan konstruksi }\end{array}$ & 0,943 & valid & & $\mathrm{H}-2$ \\
\hline & $\begin{array}{l}\text { Kontraktor, rata-rata } 31,6 \% \text { dibulatkan } \\
31,5 \%\end{array}$ & 94,5 & 5,5 & 0 & $\mathrm{STH}_{3}$ & $\begin{array}{l}\text { Masyarakat sekitar memahami dan } \\
\text { menyetu jui rencana proyek }\end{array}$ & 0,716 & valid & & H-3 \\
\hline & $\begin{array}{l}\text { Lingkungan, rata-rata } 14,16 \% \\
\text { dibulatkan } 14 \%\end{array}$ & 83,5 & 16,5 & 0 & $\mathrm{STH}_{4}$ & $\begin{array}{l}\text { Masyarakat peduli terhadap kese- } \\
\text { lamatan dan kesehatan konstruksi }\end{array}$ & $\mathbf{0 , 8 8 3}$ & & & H-4 \\
\hline
\end{tabular}


Projek A, MISAP = 58.11 sakit $=28$, luka $=4$, fatal $/$ meninggal $=0$

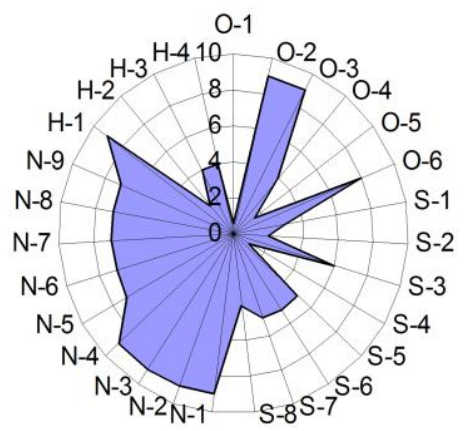

Projek C, MISAP $=51.77$ sakit $=1$, luka $=0$,

fatal $/$ meninggal $=0$, projek sedang berjalan

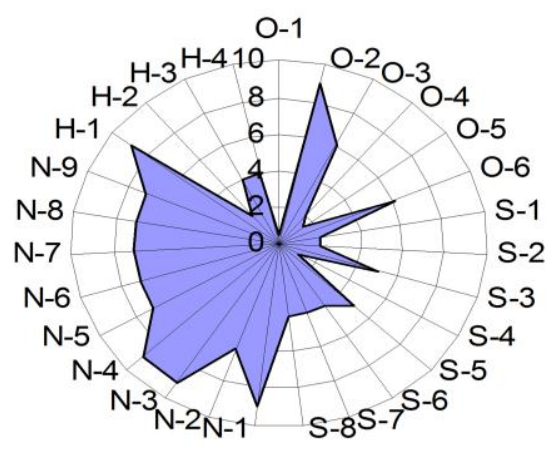

Projek B, MISAP $=17.11$

sakit $=0$, luka $=9$,

fatal $/$ meninggal $=5$

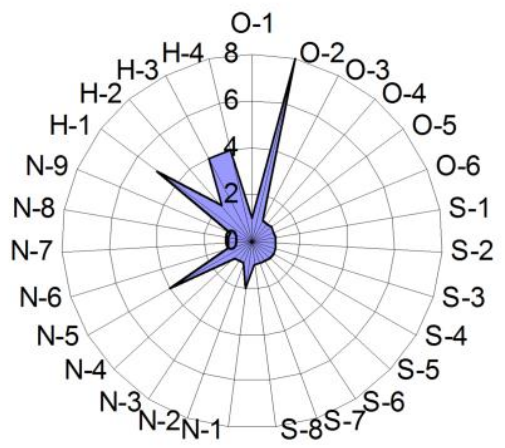

Projek D, MISAP $=55.90$

sakit $=1$, luka $=0$, fatal $/$

meninggal $=0$, projek sedang berjalan

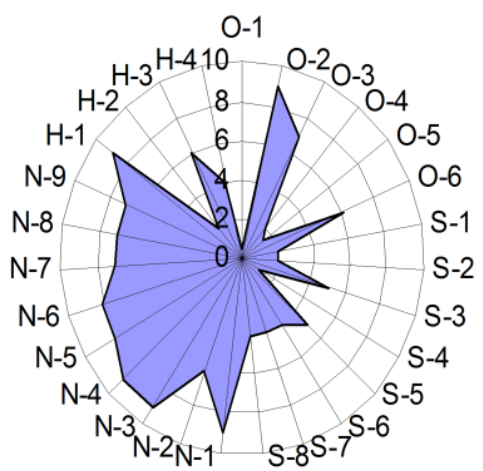

\section{Gambar 2. Indek perencanaan keselamatan (MISAP) dari beberapa proyek}

Setelah didapat model penilaian yang valid dan reliabel, dilakukan aplikasi ke beberapa proyek konstruksi, yaitu proyek A di Jakarta, proyek B di Jawa Tengah, proyek C di Jakarta, proyek D di Yogyakarta. Hasil aplikasi digambar pada Gambar 2.

\section{Kesimpulan}

Pencegahan kecelakaan konstruksi harus selalu ditingkatkan untuk menurunkan angka kecelakaan fatal menjadi seminimal mungkin. Salah satu upaya adalah menggunakan pendekatan hulu (upstream approach) untuk melengkapi pendekatan hilir (down stream approach) yang selama ini telah dilakukan. Pendekatan hulu yang dimaksud adalah perencanaan keselamatan sejak tahap pra konstruksi. Untuk menilai kematangan perencanaan keselamatan pra konstruksi, dapat dipakai model penilaian MISAP 1 yang berupa diagram "radar", atau model penilaian MISAP 2 yang berbentuk lembar observasi.

\section{Daftar Pustaka}

Barrie, Donald S., et al., 1990. Professional Construction Management, Erlangga, Jakarta.

Davies, V J and K., Tomasin, 1996. Construction safety Handbook, Thomas Telford Publishing, London.

Echols, John M., dan Hassan Shadily, 1990. An English-Indonesian Dictionary, PT Gramedia, Hal. 375, Jakarta.

ECI-Europan Construction Institute, 1995. Total Project Management of Construction Safety, Health and Environment, Thomas Telford.

Fink, Susan, 1997. Health and Safety Law for The Construction Industry, Thomas Telford Publishing, London.

Hasibuan, Malayu, 2005. Manajemen, Bumi Aksara, Jakarta. 
Hinze, Jimmie W., 1997. Construction Safety, Prentice-Hall, Inc.

Johnson, Holly M. et al., 1998. Fall Protection Analysis for Workers on Residental Roofs, Journal of Construction Engineering and Management, Sept-Okct 1998.

Kerzner, Harold, 1995. Project Management, Van Nostrand Reinhold.

Koehn, Enno et al., 1995. Safety in Defeloping Countries: Professional and Bureaucratic Problems, Journal of Construction Engineering and Management, September 1995 hal. 261 - 265.

Levitt, Raymond E., and Nancy M., Samelton, 1993. Construction Safety Management, John Wiley \& Sons, Inc, New York.

Mohamed, Sherif, 2003. Scorecard Approach to Benchmarking Organizational Safety Culture in Construction, Journal of Construction Engineering and Management, January-February 2003.

Oberlender, Garold D., 2000. Project Management for Engineering and Construction, McGraw-Hill.

Selim, Bisma R., and Julia Pet-Armacost, 2004. Program Assessment Handbook, University of Central, Florida.
Suraji, Akhmad, and A., Roy Duff, 2000. Constraint-Response Theory of Construction Accident Causation. The International Conference on Designing for Safety, ECI/CIB/HSE, London.

Suraji, Akhmad, et al., 2001. Development of Causal Model of Construction Accident Causation, Journal of Construction Engineering and Management, July-August 2001 hal. 343.

Suraji, Akhmad, and Bambang Endroyo, 2009. Kecelakaan Konstruksi: Teori dan Pengalaman Empiris, Buku Konstruksi Indonesia, Departmen Pekerjaan Umum, Jakarta.

Turoff, Murray, dan Harold, Linstone, 2002. The Delphi Method, Institute of Technology, New Yersey.

Ward, Christine, 1980. Designing a Scheme of Assessment, Stanley Thornes.

Wirahadikusumah, Reini, D., and Febby, Feisal 2005. Kajian Penerapan Pedoman Keselamatan Kerja pada Pekerjaan Galian Konstruksi, Jurnal Teknik Sipil (ITB) Volume 12 No. 2, April 2005, Bandung.

Wu et al., 2002. The Development of the Process Protocol Maping Methodology and Tool. University of Salford. 